\title{
Rainfall Variability over Tanzania during October to December and Its Association with Sea Surface Temperature (SST)
}

\author{
Hassan Khatib Ame, Agnes Lawrence Kijazi, Ladislaus Benedict Changa*, \\ Kantamla Biseke Mafuru, Mohamed Khamis Ngwali, \\ Masoud Makame Faki, Asya Omar Hmad, Miraji Khamis Miraji
}

Tanzania Meteorological Authority, Dar es Salaam, Tanzania

Email: *changa60@hotmail.com

How to cite this paper: Ame, H.K., Kijazi, A.L., Changa, L.B., Mafuru, K.B., Ngwali, M.K., Faki, M.M., Hmad, A.O. and Miraji, M.K. (2021) Rainfall Variability over Tanzania during October to December and Its Association with Sea Surface Temperature (SST). Atmospheric and Climate Sciences, 11, 324-341.

https://doi.org/10.4236/acs.2021.112019

Received: January 27, 2021

Accepted: April 11, 2021

Published: April 14, 2021

Copyright $\odot 2021$ by author(s) and Scientific Research Publishing Inc. This work is licensed under the Creative Commons Attribution International License (CC BY 4.0).

http://creativecommons.org/licenses/by/4.0/

\begin{abstract}
The current study examines the interannual rainfall variability and its associated atmospheric circulation in Tanzania during October-December (OND) rainfall season based on 1974 to 2010 climatology. The Empirical Orthogonal Function (EOF), composite and correlation analysis were used in this study. Years with enhanced precipitation are found to be associated with the low level moist and unstable wind from Congo basin which organizes and forms a confluent zone, an inter tropical convergence zone (ITCZ) extending from Congo to northern sector of the country. It however, characterizes low-level westerly moisture flux transport sourced from Congo basin, ascending limb of the local Indian Ocean Walker circulation over East Africa which enhances convection for wetness condition. Wet years are also coupled with the positive Indian Ocean Dipole (IOD) and the warm phase of the El Nino Southern Oscillation (ENSO) condition. On the spatial scale, both the IOD and ENSO indices are well correlated with OND rains over the bimodal areas (Lake Victoria basin, North Eastern Highlands (NEH), and northern coast) with strong correlation being to the NEH. Strong temporal correlation is revealed between the OND rains and IOD $(r=0.6304)$ compared to ENSO $(r=0.5538)$ indicating that anomalous warming over the western Indian Ocean has a faster response to OND rains in Tanzania than the remote influence induced by anomalous warming from the central Pacific Ocean. The patterns associated with dry years are found to be linked with the low-level divergence accompanied by convergence in the upper level. This condition enhances continuous descending motion accompanied with suppression in rainfall activities. Dry years are also associated with negative IOD, cold phase of ENSO condition, descending limb of the Walker Circulation and significant reduc-
\end{abstract}


tion in the westerly moisture flux transport sourced from Congo basin towards the western sector and Lake Victoria basin.

\section{Keywords}

OND Rainfall, Empirical Orthogonal Function, Correlation, Tanzania

\section{Introduction}

Understanding the inter-annual variability of rainfall in Tanzania is of crucial importance to all socio-economic sectors, particularly sectors that are very sensitive to climate variability including agriculture, infrastructure, fisheries, hydro-electric power generation and water resources. Some researchers [1] [2] noted that, rainfed agriculture is the source of livelihood of about $70 \%$ of the population in sub-Saharan Africa, while for Tanzania, rain-fed agriculture is the main source of livelihood to about $75 \%$ to $80 \%$ of the population, and agricultural activities account for $25 \%$ of the Gross Domestic Product, GDP [3].

Rainfall distribution in Tanzania exhibits a stronger spatial and temporal variability characterized by frequent occurrence of extreme events including severe and devastating droughts and floods. The occurrence of these extremes often causes severe consequences to the livelihoods, infrastructure, food insecurity, energy and water shortages, and deaths of human beings and animals [4] [5] [6].

Enhanced understanding of rainfall variability provides better inputs and contributions for understanding the dynamics and evolution of the climate system and its associated variability and predictability. Understanding the trend of rainfall variability also helps to generate more understanding about the dynamics and consequence of climate change and variability on environmental and human system [7]. It is well documented that the impact of climate change on agriculture in developing countries has been increasing causing decrease in agricultural production and productivity [8].

The study of East African rainfall, particularly the nature and extent of its variability has received considerable attention and is well documented by a number of researchers. For instance, [9] associated the East African rainfall with the passage of the ITCZ in such a way Tanzania is under the influence of ITCZ during the month of October to May. It is also revealed that El Nino Southern Oscillation (ENSO) plays a significant role in determining the monthly and seasonal rainfall pattern in Tanzania and East Africa [10] [11] [12] [13] and [14], with warm events being associated with high rainfall while cold events with low rainfall. It was however, noted that the robust relationship of the East African rainfall is found to be during OND rain season [10] [15] and weak in MAM. Some studies [16] [17] [18] [19] showed a coherent association of the Indian Ocean dipole (IOD) with several flooding events across East African region. According to [20], the positive IOD events are associated with enhanced rainfall activities 
over Eastern Africa through the anomalously strengthened tropical easterly jet stream. Conspicuously, the co-occurrence of the canonical El-Niño Madoki and positive IOD may tend to induce strong anomalous enhancement in rainfall over the Eastern Africa region. The recent study by [21] has extensively associated the wetness and dryness conditions during OND rainfall season with the Walker Circulation. In their findings it was noted that, the wetness (dryness) condition is linked with the rising (descending) limb of the Walker circulation over the western Indian Ocean (WIO). Thus, during positive Indian Ocean Dipole (IOD) events, the Walker circulation cell over the Indian Ocean is well defined, and more comparable than it does during El Niño years. In El Niño years, the Walker circulation cell becomes weak compared with positive IOD events, where the zonal winds strengthen, resulting in active convective activities over the WIO. With this case, the Walker circulation cell developing over the Indian Ocean is strongly connected to IOD activity. The weakening of the Walker circulation cell is likely the reason for the decrease in OND rainfall during El Niño events compared with that of positive IOD events in recent years over Tanzania. In spite of the development made in climate variability research over the region over the last few decade, but still several gaps in knowledge and understanding about the forcing factors and their evolution exists. These include understanding the main circulation anomalies linked with variability of OND rainfall including the wet and dry years. To bridge this gap, the current study focuses on the inter-annual variation of the OND rainfall season in Tanzania to identify and characterize the associated circulation anomalies.

\section{Data and Methodology}

\subsection{Data Description}

This study utilized the monthly rainfall data sets from 17 synoptic stations from Tanzania Meteorological Authority (TMA), in Figure 1 based on 1974-2010 climatology. The average seasonal rainfall values for OND season were computed from the monthly observed data sets. Correspondingly, the average monthly gridded precipitation data sets from the Global Precipitation Climatology Centers (GPCC) were also used. These data spans with a spatial resolution of $0.5^{\circ} \times 0.5^{\circ}$ grid and extended from 1901 to present. The National Centers for Environmental Prediction-National Center for Atmospheric Research (NCEPNCAR) monthly mean reanalysis datasets from 1949 to present [22] provide a gridded analysis of the global observational network of meteorological variables (i.e., relative humidity, specific humidity, velocity potential, zonal and meridional wind components) that were used in this study. The data spans with a spatial resolution of $2.5^{\circ} \times 2.5^{\circ}$ grid at every 6 hours. The monthly mean sea surface temperature data were obtained from the National Oceanic and Atmospheric Administration (NOAA) with a $2.0^{\circ}$ latitude-longitude resolution [23]. On the other hand, the IOD indices were obtained from the difference between SST anomalies observed between the western Indian Ocean $\left(50^{\circ} \mathrm{E}-70^{\circ} \mathrm{E}, 10^{\circ} \mathrm{S}-\right.$ 

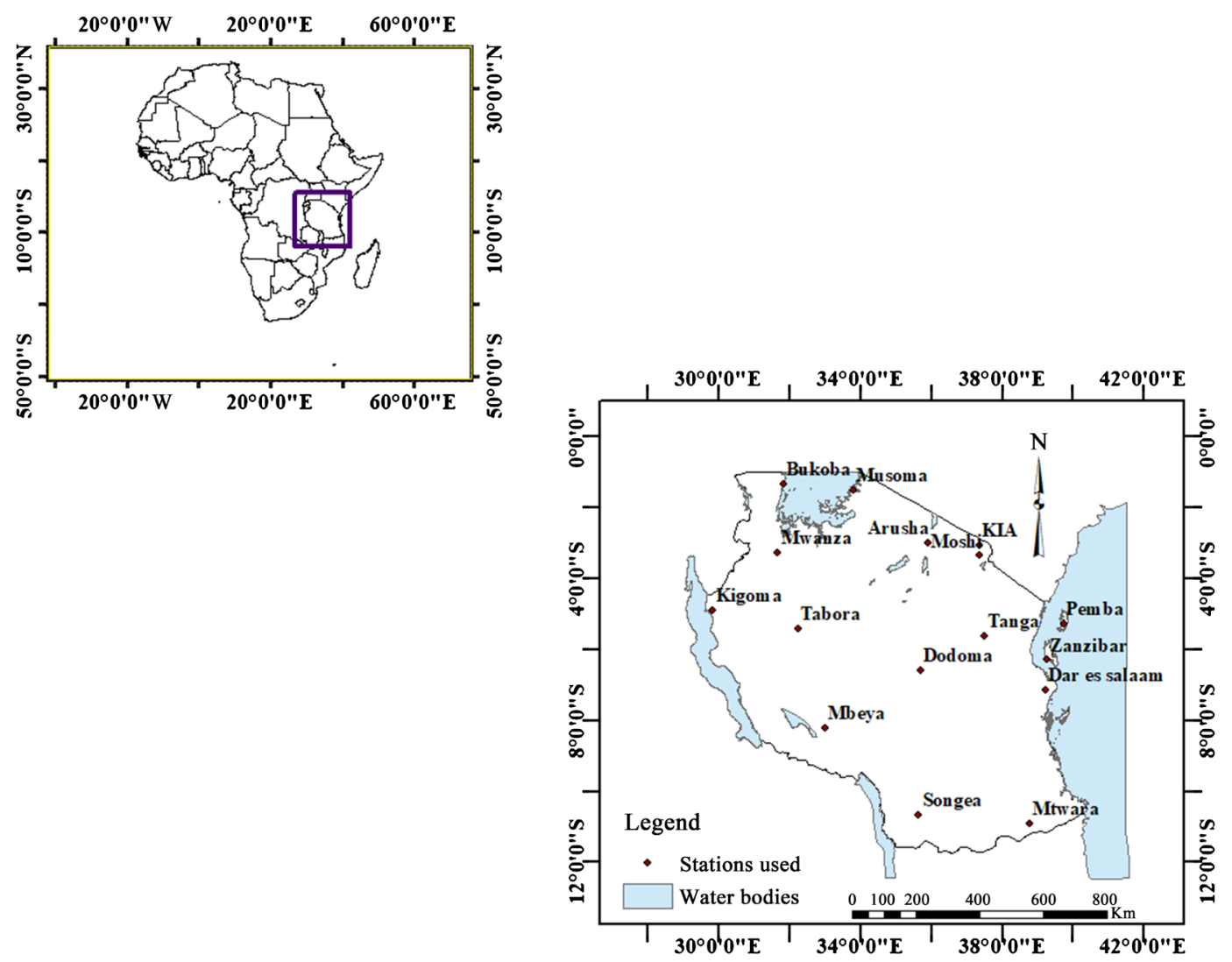

Figure 1. The map of Africa showing the geographical location of Tanzania and stations used in the study (source: reconstructed with ArcGIS software).

$\left.10^{\circ} \mathrm{N}\right)$ and eastern Indian Ocean $\left(90^{\circ} \mathrm{E}-110^{\circ} \mathrm{E}, 10^{\circ} \mathrm{S}-0^{\circ}\right)$ as it has been used by a number of researchers [24] [25] [26].

\subsection{Methodology}

The present study utilized the empirical orthogonal function (EOF) to explore the leading climatic modes from the mean OND observed rainfall from 17 synoptic stations scattered over Tanzania (Figure 1) based on 1974 to 2010 climatology. EOF analysis is frequently applied to derive patterns and indices used to identify climate modes as expressed in state variables [27]. The approach identifies patterns in space known as EOF modes in one or multiple variables from eigenvectors of the covariance matrix for the gridded data sets. Then the original centered data are projected onto the spatial patterns to obtain time series indices (i.e., the principal components). Therefore, the first EOF spatial mode of the mean OND rainfall was taken as the dominant mode and further explained areas that were prone to wetness/dryness over the entire climatology. Quantifying the relationship between IOD and mean rainfall during OND over the study domain, we first define their respective indices. The process of developing these indices does not only tie in exploring the existing association between the two but also quantify when both indices show a relatively strong association. Having realized that the principal component time series provides the strength of EOF pat- 
tern over time, we assign the first principal component (i.e., PC1, in Figure 4(b)) to represent the OND rainfall indices. Correspondingly, the IOD index was obtained by subtracting the SST of the eastern Indian Ocean $\left(90^{\circ} \mathrm{E}-110^{\circ} \mathrm{E}\right.$, $\left.10^{\circ} \mathrm{S}-0^{\circ}\right)$ from the western Indian Ocean $\left(50^{\circ} \mathrm{E}-70^{\circ} \mathrm{E}, 10^{\circ} \mathrm{S}-10^{\circ} \mathrm{N}\right)$. Ascertaining the circulation anomalies responsible for the wetness/dryness condition during OND, the current study carried a composite analysis on a number of field variables and later test for their significance with the two tailed Student's t-test. Noted that, the composite for the wet years is computed when the amplitude of the rainfall indices is greater than or equal to +1 . On the other hand, for the dry years, the amplitude of less than or equal to -1 is said to be linked with dry years.

\section{Results and Discussion}

\subsection{The Climatic Characteristic of Rainfall in Tanzania}

The validation of the CRU and GPCC data sets against the observed rainfall data sets was done by comparing the CRU and GPCC data with observed station data over Tanzania. The process enabled the identification of a better dataset among the two in reproducing the annual rainfall over Tanzania that can be used instead of observed rainfall data sets which are generally incomplete and short in spatial distribution. Both the CRU and GPCC data sets were therefore extracted as an aerial average from Tanzania domain (i.e., $12^{\circ} \mathrm{S}-1^{\circ} \mathrm{S}$ and $30^{\circ} \mathrm{E}-40^{\circ} \mathrm{E}$ ) and compared to the country average of observed station data sets. Both the CRU and GPCC data sets are in agreement with the observed rainfall data sets, and the pattern from all data sets reproduces the two rainfall peaks during MAM and OND seasons (Figure 2(a)) and are consistent with the earlier findings [28]. The pattern from June to December (i.e., including the period under study, October-December), also indicates that both CRU and GPCC gridded data sets are more closely related with the observed data. However, much weight is given to the CRU data sets since it is highly correlated with the observed rainfall data sets $(r=0.9013)$ than the GPCC $(r=0.8818)$. In this case the CRU data set was chosen for further analysis to understand the long-term rainfall variability over Tanzania.

The climatological distribution of rainfall in October (Figure 3(a)) shows that there are more rains to the Lake Victoria basin, extreme western sector (mainly northern Kigoma) and to the peripheral of the northern coast of the country. This condition suggests the fact that, during OND rainfall season the onset starts from the western and Lake Victoria basin then spreading to the rest of the area as the season progresses. However, the rest parts of the country record less amount of rainfall (less than $50 \mathrm{~mm}$ ) in October.

During November (Figure 3(b)) the western and majority of the bimodal areas reveal noticeable amount of rainfall while the unimodal areas (i.e., central, south-western highlands, SWH and southern region) records less amounts. This condition can be attributed by the fact that during this period the ITCZ is still 
(a) The annual Rainfall Cycle over Tanzania

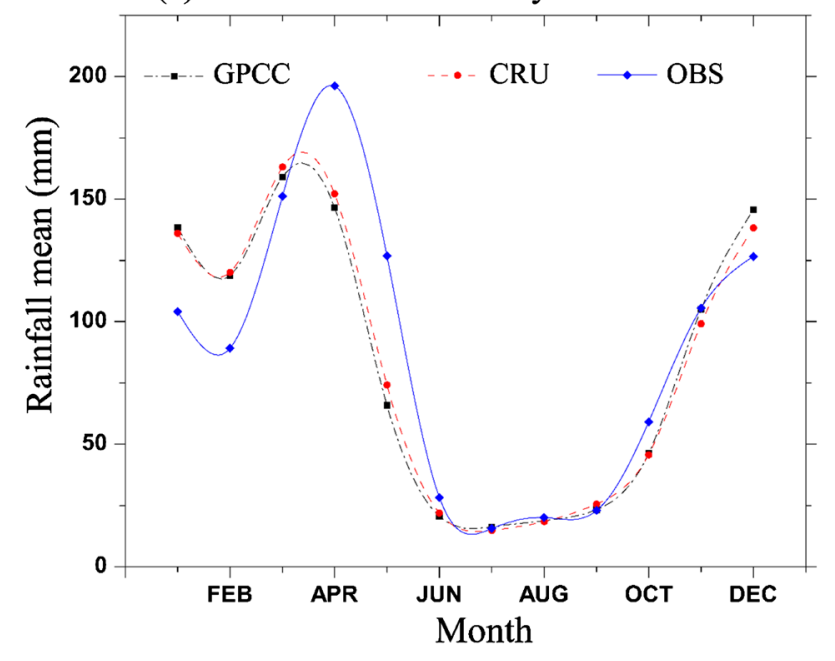

(b) Seasonal Rainfall contribution

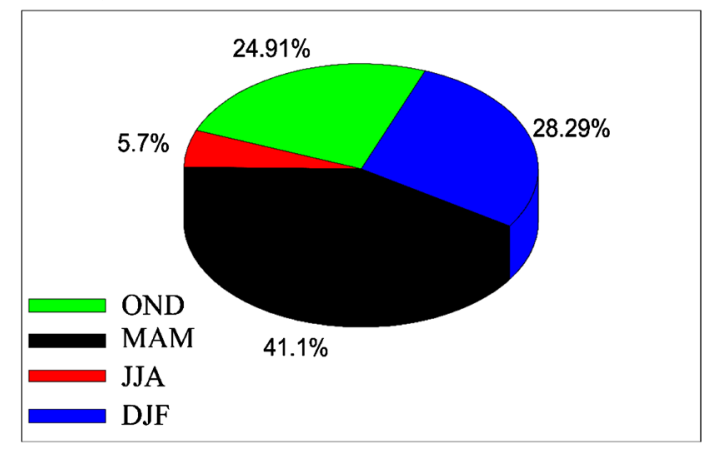

Figure 2. (a) The annual cycle of rainfall in Tanzania ( $\mathrm{mm})$ computed as the areal average of the country (i.e., $12^{\circ} \mathrm{S}-1^{\circ} \mathrm{S}$ and $30^{\circ} \mathrm{E}-40^{\circ} \mathrm{E}$ ) from GPCC (black dashed line), CRU (red dashed line with cycles) and observed rain-gauge data sets (blue solid line); (b) Seasonal rainfall contribution based on 1974 to 2010 climatology.

further North of the country. Subsequently, with the gradual southward movement of the ITCZ, causing majority of the unimodal areas (West, central, SWH, southern region and southern coast) in Figure 3(c) to be characterised with enhanced rainfall in December. It is however noted that, November marks the mid of the OND season and characterises enhanced rainfall over the bimodal areas while December (Figure 3(c)) marks the end of the OND season with enhanced rainfall to unimodal areas. Figure 3(d) shows the long term mean rainfall during OND rainfall season in Tanzania. During this season the majority of the areas in the country receives high amount of rainfall with an exception of the central areas and some parts of the north eastern highlands. Enhanced amount of rainfall is well observed over the bimodal areas (mainly extreme northern parts of Kigoma and western Lake Victoria basin).

\subsection{The OND Rainfall Variability}

EOF analysis in this study is used to investigate the variability of OND rainfall in Tanzania based on 1974 to 2010 climatology. The first three EOF patterns ex- 
plain more than $76.89 \%$ of the total variance and therefore being more representative of the country's seasonal rains variability during OND season. Figure 4(a) depicts the dominant mode (EOF1) and its corresponding principal component time series (PC1, in Figure 4(b)) for the mean monthly rainfall anomalies over Tanzania based on 1974-2010 climatology. EOF1 accounts for more than $61.57 \%$ of the total variance and exhibits the monopole mode of variability with positive loadings concentrating over the majority of the areas within the country (Figure 4(a)).

The strongest positive loadings concentrate to the northern sector, eastern

(a) October

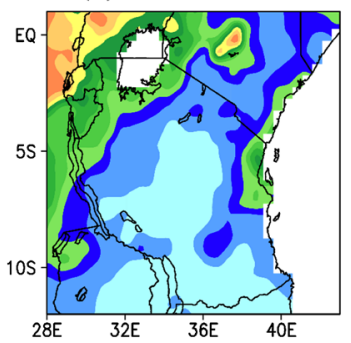

(c) December

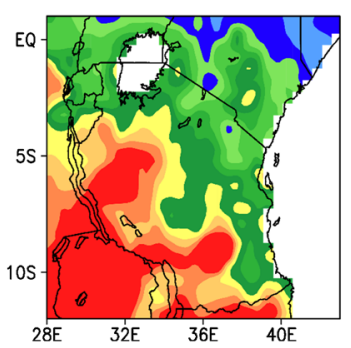

(b) November

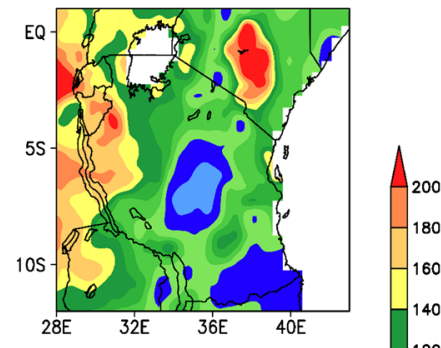

(d) OND

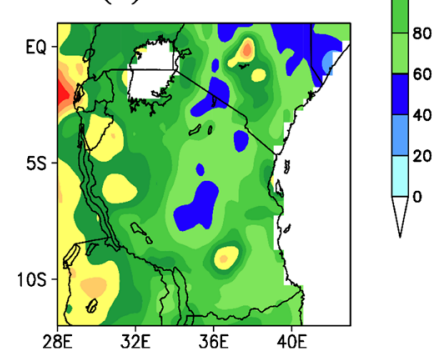

Figure 3. The spatial mean monthly rainfall distribution in Tanzania during (a) October (b) November (c) December (d) October to December (OND) based on 1974 to 2010 climatology.

(a) EOF1 (61.57\%)

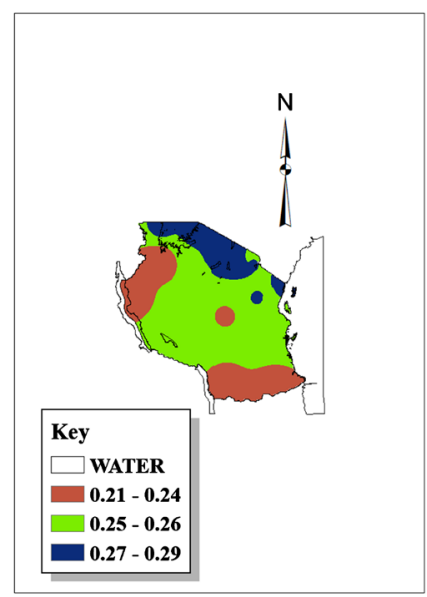

(b) PC1

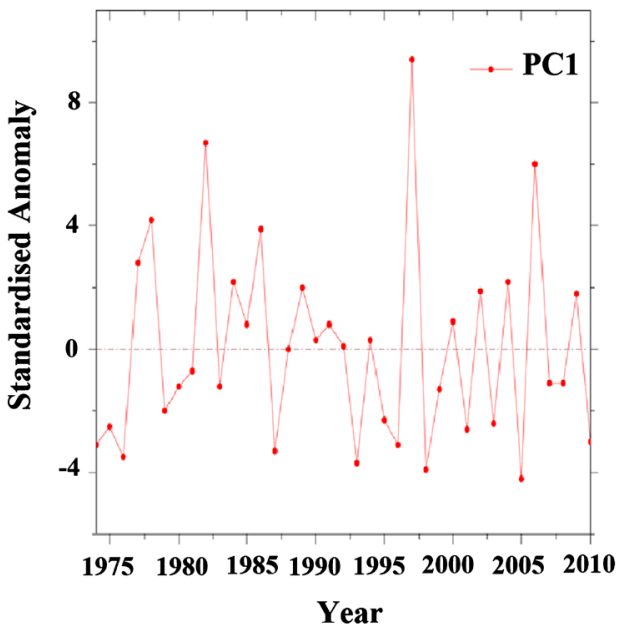

Figure 4. (a) The spatial pattern of the first EOF mode (EOF1) and its corresponding PC time series in (b), of the mean rainfall during OND season based on 1974-2010 climatology. 
sector and northern coast areas of the country. Weak loadings are observed over the western, central, southern region and southern coast of the country. The results suggest that variability of precipitation over study area during OND is uniform with more rainfall over the northern sector, eastern sector and northern coast of the country. This is consistent with long term mean rainfall during OND season in Tanzania (Figure 3(d)). Meanwhile, Figure 5(a) \& Figure 5(b) show the spatial patterns of the second (EOF2) and third (EOF3) modes of EOF during OND rainfall season. EOF2 in Figure 5(a) explains $7.72 \%$ of the total variances with bipolar mode of variability. Much of the positive loading are located over the western, central and southern part of the study area while negative loading to northern and eastern sector of the country. Moreover, EOF3 accounts for $7.60 \%$ of the total variance with positive loading dominating the southern sector, extreme western sector and to a lesser extent a small area of the north eastern highlands (Figure 5(b)) with the remaining part being dominated by negative loadings.

\subsection{Relative Influence of Wetness/Dryness Condition during OND}

Determining the influence of extreme wet and dry conditions during OND season we carried out the composite analysis for a number of field variables. The basis for the composite relies on the principal component time series (PC1, in Figure 4(b)) for the OND rainfall expansion. Years with strong amplitude of normalized mean OND rainfall departures of $\geq+1$ of the standard deviation (1978, 1982, 1986, 1997 and 2006) and those ones with strong amplitudes of normalized departures of $\leq-1$ of the standard deviation $(1976,1987,1993,1998$ and 2005) were selected as wet and dry years respectively.

\subsubsection{Wind and Moisture Flux Anomaly}

Figure 6 shows the spatial pattern for the composite wind vector anomalies at 850 and $200 \mathrm{hPa}$ during wet and dry years of the OND season based on 1974 to

(a) EOF2 (7.72\%)

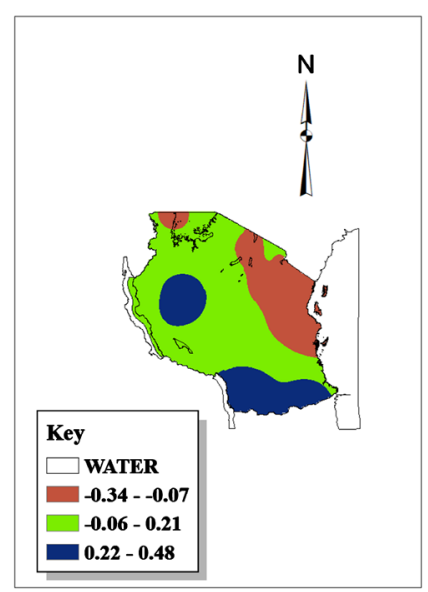

(b) EOF3 (7.60\%)

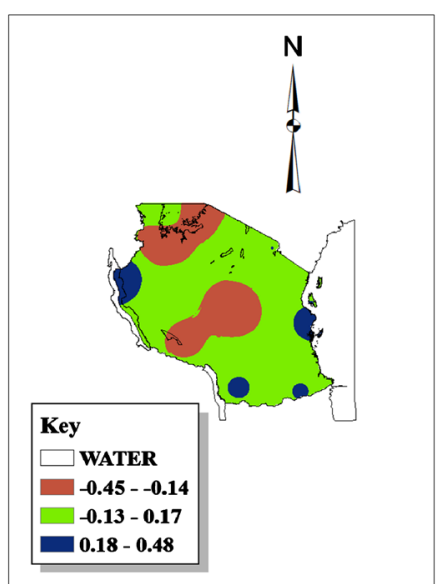

Figure 5. The spatial pattern of (a) the second EOF mode (EOF2) and (b) the third EOF mode (EOF3) of the mean rainfall during OND season based on 1974-2010 climatology. 
(a) $850 \mathrm{hPa}, \mathrm{UV}$ (Wet Years)

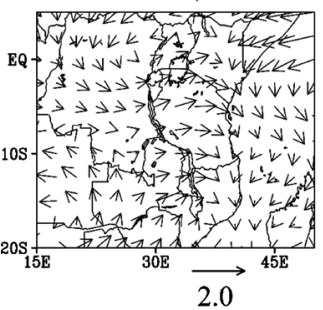

(c) $850 \mathrm{hPa}$, UV (Dry Years)

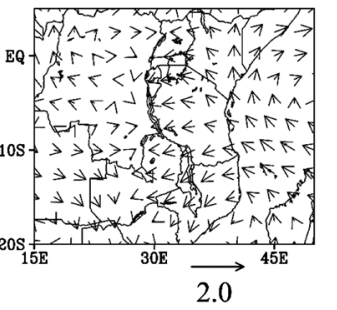

(e) $850 \mathrm{hPa}, \mathrm{UV}$ (Wet-Dry)Years

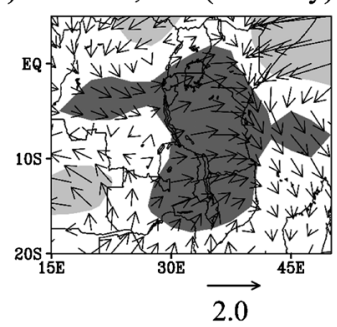

(b) $200 \mathrm{hPa}, \mathrm{UV}$ (Wet Years)

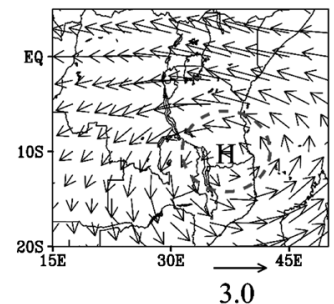

(d) $200 \mathrm{hPa}, \mathrm{UV}$ (Dry Years)

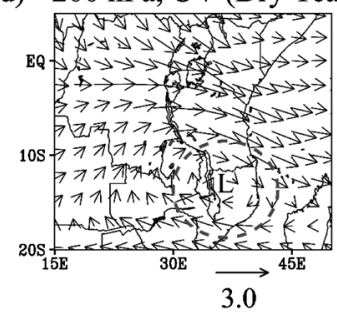

(f) $200 \mathrm{hPa}, \mathrm{UV}$ (Wet-Dry)Years

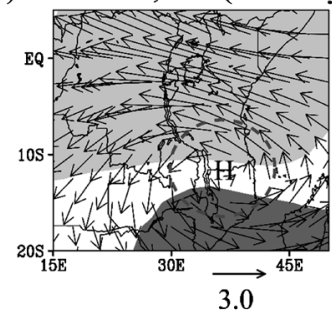

Figure 6. The composite wind vector anomalies for wet years at (a) $850-\mathrm{hPa}$ (b) $200-\mathrm{hPa}$; dry years at (c) $850-\mathrm{hPa}$ (d) $200-\mathrm{hPa}$ and the difference between wet and dry years at (e) $850-\mathrm{hPa}(\mathrm{f}) 200-\mathrm{hPa}$. Shaded areas are significant regions at t-test based on $95 \%$ confidence interval.

2010 climatology. The results show that during wet years at $850 \mathrm{hPa}$, the moist and unstable wind from Congo basin organizes and forms a confluent zone (ITCZ) extending from Congo to northern sector of the country (Figure 6(a)). It however converges with the maritime north easterly wind from the Indian Ocean mainly to the northeastern highlands and northern coast of the study area, and probably being the source of enhanced precipitation during the season. Noted that, the low-level convergence is accompanied by the high-pressure system in the upper level (see dotted circular line in Figure 6(b)) favoring enhanced convection alongside. Remarkably, significant changes are observed in dry years (Figure 6(c)), where the low level south easterly wind anomalies dominate and diverge over many parts of the country. Correspondingly, cyclonic circulation at the upper level (Figure 6(d)) is aligned with the low-level divergence in Figure 6(c). This situation is consistent with a study done by Barry et al, (2003) which revealed that convergence at low level gives rise to vertical stretching, whereas divergence results in vertical shrinking suppressing convection due to subsidence. Further, Hastenrath (2007) and, [29] confirmed that westerly wind anomaly flow sourced from Congo basin are associated with enhanced East African precipitation.

Figure 6(e) revealed significant westerly wind anomalies sourced from Congo 
converge over the northern sector (bimodal rainfall regime domain) of the study area. Meanwhile, it also resumes repositioning of the high-pressure cell over the southern sector of the country (Figure 6(f)) in the upper level which ensures enhanced convection alongside. Studying the influence of the low-level moisture transport during the wet and dry years of OND season we focused our analysis on the $850 \mathrm{hPa}$ level since it is considered to be the most significant representative behavior of the vertically integrated moisture flux over eastern Africa [29].

Generally, the eastern half of the study area is dominated by the low-level westerly moisture flux transport sourced from Congo basin (Figure 7(a)). However, strong weight of the moisture flux transport is located to the north-south corridor (i.e., north eastern highlands, northern coast; Tanga, Pwani, Morogoro and Dar es Salaam regions, and southern region) of the country (Figure 7(a)). On the other hand, there is deficit of moisture flux transport from the western sector and the entire Lake Victoria basin sourced from Congo basin (Figure 7(a)). Since the moisture flux divergence is negative over the eastern half of the study area with enhancement to the north-south corridor (i.e., north eastern highlands, northern coast; Tanga, Pwani, Morogoro and Dar es Salaam regions, and southern region) it is therefore consistent with the enhanced convergence in moisture

(a) $850 \mathrm{hPa}$ Moisture Flux Divergence (Wet Years)

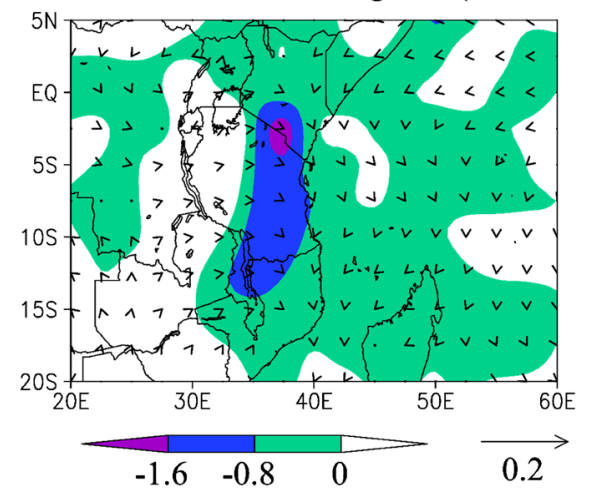

(b) $850 \mathrm{hPa}$ Moisture Flux Divergence (Dry Years)

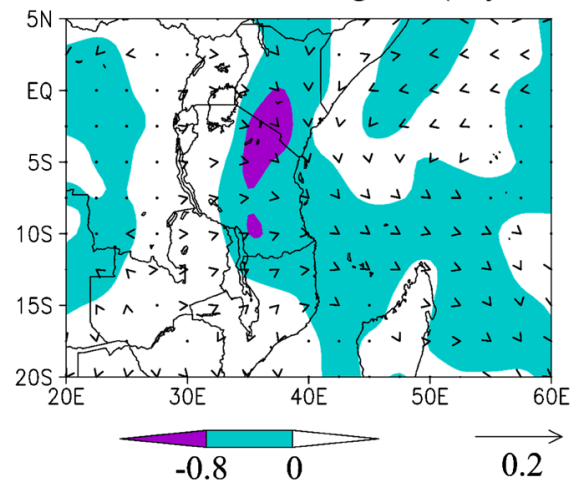

Figure 7. The $850 \mathrm{hPa}$ composite anomaly fields of the moisture flux (vectors) and its divergence (shading) during (a) wet years (b) dry years based on 1974 to 2010 climatology. Noted that, negative (positive) shading represents convergence (divergence) respectively. The scale vector corresponds to moisture flux $0.2 \mathrm{~g} / \mathrm{kg} \mathrm{m} / \mathrm{s}$ and the moisture flux divergence contour interval is $2 \times 10^{-8} \mathrm{~g} / \mathrm{kg} / \mathrm{s}$. 
flux leading into increased wetness condition within the region (Figure 4(a)). In this case, it explains how important the westerly wind anomalies in Figure 6(a) are advecting the low-level moisture flux from Congo Basin towards the country for enhanced convection and wetness condition. During dry years (Figure 7(b)), there is significant reduction in the westerly moisture flux transport sourced from Congo basin towards the western sector and Lake Victoria basin. However, moisture flux transport persistence is observed over the eastern half of the country sourced from the southern part of Kenya and the Indian Ocean (Figure $7(b))$. This scenario confirms the significant importance of the Indian Ocean in advecting moisture for enhanced convection and wetness over many areas of the eastern sector (i.e., along the coastal belt).

\subsubsection{Velocity Potential and Divergent Wind Anomaly}

Figure 8 shows the composite velocity potential and divergent/convergent wind anomalies during wet conditions of OND season based on 1974 to 2010 climatology. The centers of low (high) velocity potential are accompanied by divergent outflow (confluent inflow) of winds. Correspondingly, divergence (convergence) in the upper troposphere (i.e., $300 \mathrm{hPa}$ ) is coupled with convergence (divergence) in the lower troposphere. During wet years, the western Indian Ocean is characterized with the low tropospheric convergence (Figure 8(a)) coupled with diffluent flow in the upper level (Figure 8(b)). The convergent center West of the Indian Ocean in Figure 8(a) is organized in such a way to the western part of the study area the wind flows eastwards (i.e., with northwesterly component in the lower troposphere and crosses Congo, thereby advecting moist wind towards the study area). The positive velocity potential and wind convergence over the western Indian Ocean (i.e., centered over Eastern Tanzania in Figure $8(a)$ ) coupled with the negative velocity potential and upper tropospheric wind divergence (Figure 8(b)). This condition reflects the positioning of the ascending limb of the local Indian Ocean Walker circulation over East Africa which

(a) $850 \mathrm{hPa}$ Composite V. Potential (Wet-Dry) Years of OND

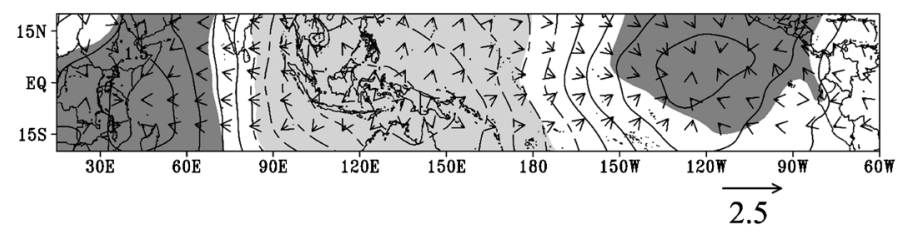

(b) $300 \mathrm{hPa}$ Composite V. Potential (Wet-Dry) Years of OND

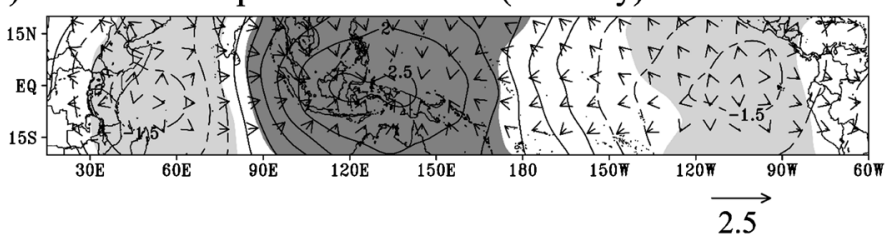

Figure 8. The composite pattern for the velocity potential $\left(10^{6} \mathrm{~m}^{2} \cdot \mathrm{s}^{-1}\right)$ and divergent wind $\left(\mathrm{m} \cdot \mathrm{s}^{-1}\right)$ anomalies, being the difference between wet and dry years at (a) $850 \mathrm{hPa}$ and (b) $300 \mathrm{hPa}$ during OND season of 1974 to 2010 climatology. Shaded areas are statistically significant at $5 \%$ level with a two tailed Student's $\mathrm{t}$ test. 
enhances convection for wetness condition bearing in mind that there is plenty of moisture being advected to the study area.

\subsubsection{Sea Surface Temperature Anomaly}

Figure 9 represents the composite sea surface temperature anomaly for the wet, dry and differences between wet and dry years during OND season. There are enhanced warm SST anomalies over the western Indian Ocean with cool SST anomalies to its counter parts the eastern Indian Ocean (Figure 9(a)) during wet years. Also, it reveals enhanced warm SST anomalies over the central Pacific (i.e., over Niño 3.4 region). This condition generally recaptures the positive IOD condition and warm phase of ENSO (i.e., El Nino condition). Meanwhile, cool (warm) SST anomalies are depicted over the western (eastern) Indian Ocean during dry years with cool SST anomalies over the central Pacific Ocean (Figure 9(b)). This scenario recaptures both the negative IOD condition and cold phase of ENSO (i.e., La Nina condition). The pattern of the SST anomalies for the difference between wet and dry years indicated in Figure 9(c) is also in agreement that enhanced wet condition during OND season is influenced by both the positive phase of IOD and ENSO condition. Having noted the influence of IOD and ENSO on OND rains in Tanzania, we expanded our finding trying to reveal the strength of each index in affecting the seasonal rains. Therefore, this research carried the in-phase correlation analysis between the IOD, ENSO and OND rains over Tanzania. Spatially, both the IOD and ENSO indices are found to have well correlated with OND rains over the bimodal areas (Lake Victoria basin, NEH and northern coast) with strong correlation being over the north eastern highlands (Figure 10(a) and Figure 11(a)). The time series correlation coefficient between the IOD, ENSO and OND rains shows that strong correlation exists $(r=0.6304)$ with IOD (Figure $10(b))$ compared to ENSO $(r=0.5538)$ as indicated in Figure 11(b)). In this case, it can be noted that, anomalous warming

(a) Composite SSTA during wet years in OND season

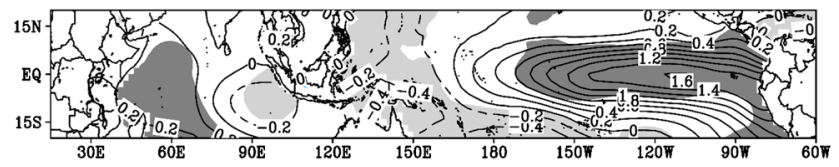

(b) Composite SSTA during dry years in OND season

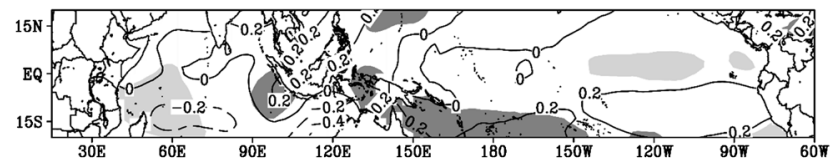

(c) Composite SSTA, (wet -dry) years in OND season

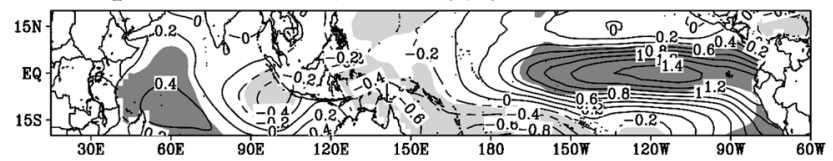

Figure 9. The composite SST anomalies for (a) wet years (b) dry years (c) the difference between wet and dry years during OND season of 1974 to 2010 climatology. The shaded areas are statistically significant at $5 \%$ level with a two tailed Student's $t$ test. 
(a) Correlation (IOD and OND rain)

(b) Inter annual variability (IOD and OND rain)
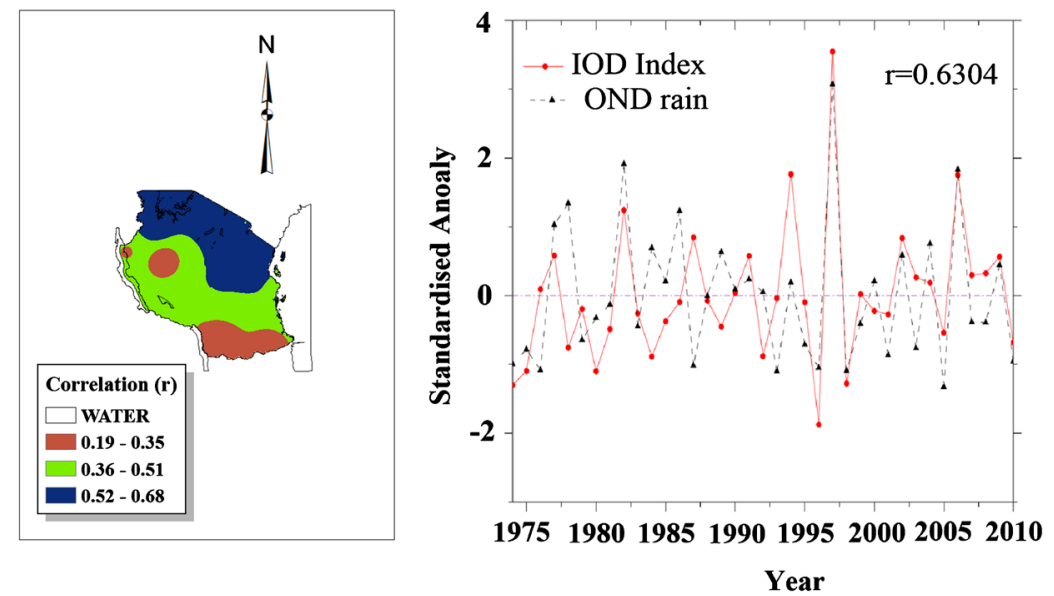

Figure 10. (a) Spatial map for the correlation between OND rainfall over Tanzania and IOD Index and (b) the time series inter annual variability between OND rainfall over Tanzania and IOD Index based on 1974 to 2010 climatology.

(a) Correlation (ENSO and OND rain)

(b) Inter annual variability (ENSO and OND rain)
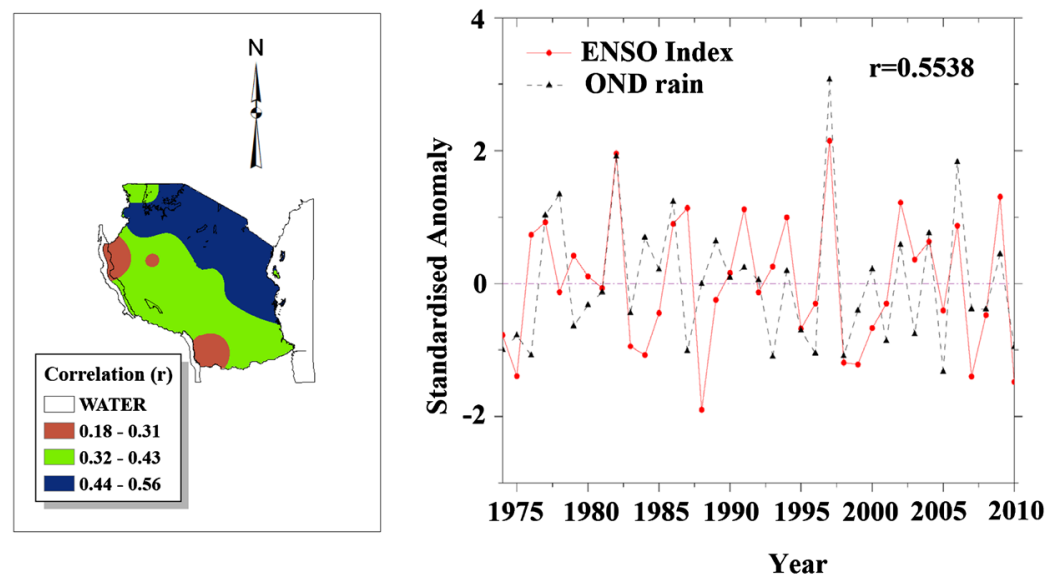

Figure 11. (a) Spatial map for the correlation between OND rainfall over Tanzania and ENSO Index and (b) the time series inter annual variability between OND rainfall over Tanzania and ENSO Index based on 1974 to 2010 climatology.

over the western Indian Ocean has a faster response to OND rains in Tanzania compared to the remote influence induced by anomalous warming from the central Pacific Ocean.

Furthermore, the current study has revealed that there is persistence strong maritime easterly wind from the Indian Ocean towards the study area with very weak westerly wind anomaly from Congo basin towards the study area during positive IOD events (Figure 12(a)). However, the dual influence of westerly wind anomalies (sourced from Congo basin) and maritime easterly anomalies (from the Indian Ocean) as indicated in Figure 12(b) are well observed to be the key factors advecting moisture for enhanced wet condition during warm phase of ENSO. Interestingly, during years with both positive IOD and warm phase of ENSO (Figure 12(c)), indicates the clear development westerly wind anomaly 
(a) $850 \mathrm{hPa}$ UV anomalies (+ve IOD Years)

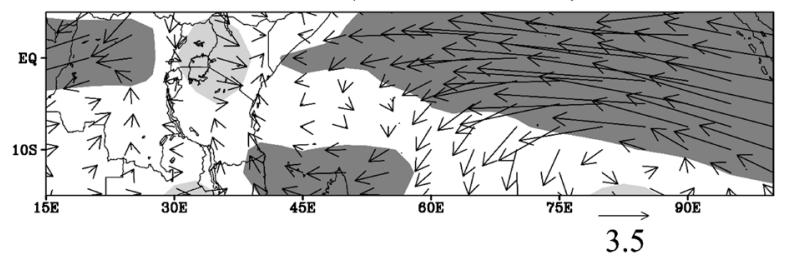

(b) $850 \mathrm{hPa}$ UV anomalies (+ve ENSO Years)

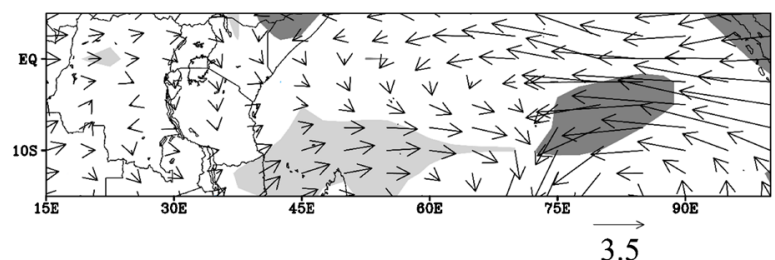

(c) $850 \mathrm{hPa}$ UV anomalies (+ve ENSO and IOD Years)

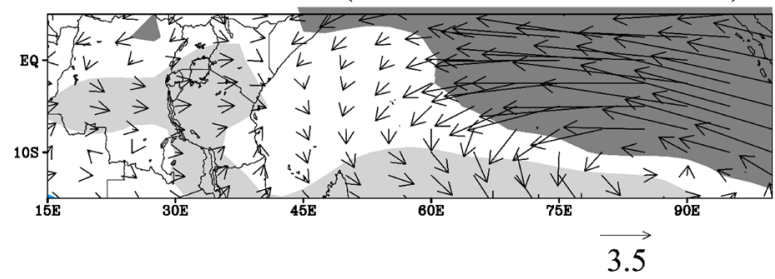

Figure 12. The $850 \mathrm{hPa}$ composite wind vector anomalies during (a) positive IOD (b) warm phase of ENSO (c) both positive IOD and warm phase of ENSO based on 1974 to 2010 climatology. Shaded areas are significant regions at $t$-test based on $95 \%$ confidence interval.

(from Congo basin) and maritime easterly wind converges over the northern sector of the country.

\section{Summary and Conclusion}

The current study investigated the spatial and inter annual variability of the OND rains in Tanzania together with the likely circulation anomalies associated with wet/dry condition based on 1974 to 2010 climatology. It has been noted that, the distribution of rainfall during October shows that there are more rains over the Lake Victoria basin, extreme western sector (mainly northern Kigoma) and to the peripheral of the northern coast of the country, thus, suggesting the fact that, in OND rainfall season the onset starts from the western and Lake Victoria basin then spreading to the rest of the areas as the season progresses. Understanding the dynamics of onset and cessation is very informative and a good input for enhanced forecasting accuracy of rainfall onset and cessation which has been very elusive over the years. In November the western and the majority of the bimodal areas recorded a relatively high amount of rainfall while the unimodal areas (i.e., central, south-western highlands, SWH and southern region) records less amounts. This condition can be attributed to the movement and relative position of the ITCZ, which during this period is still further North of the country. Generally, during OND rainfall season the majority of the areas in the country receive a high amount of rainfall with an exception of the central 
areas and some parts of the north eastern highlands. Enhanced rainfall amount is well observed over the bimodal areas (mainly extreme northern parts of Kigoma and western Lake Victoria basin).

Subsequently, the study examined the circulation patterns that are associated with the wet/dry years during OND season of 1974 to 2010. The composite for the wet years was computed when the amplitude of the rainfall indices is greater than or equal to +1 while for the dry years, the amplitude of less than or equal to -1 was considered to be linked with dry years. The observed circulation patterns indicate that, wet years are coupled with the low level moist and unstable wind from Congo basin which organizes and forms a confluent zone (ITCZ) extending from Congo to northern sector of the country. These winds converge with the maritime north easterly wind from the Indian Ocean mainly to the northeastern highlands and northern coast of the study area, and are among the potential cause for enhanced rainfall during the season.

The study also noted that, wet years are dominated by low-level westerly moisture flux transport sourced from Congo basin with strong weight being to the north-south corridor (i.e., north eastern highlands, northern coast; Tanga, Pwani, Morogoro and Dar es Salaam regions, and southern region) of the country, and describe the importance of the westerly wind anomalies in advecting the low-level moisture flux from Congo Basin towards the country for enhanced convection and wetness condition. Furthermore, the composite velocity potential anomalies reflect the positioning of the ascending limb of the local Indian Ocean Walker circulation over East Africa which enhances convection for wetness condition bearing in mind that there is plenty of moisture being advected to the study area.

We also found that, wet years are generally associated with the positive IOD condition and the warm phase of the ENSO condition. On the spatial scale, it was revealed that both the IOD and ENSO indices are well correlated with OND rains over the bimodal areas (Lake Victoria basin, NEH and northern coast) with strong correlation being over the north eastern highlands. There was a strong temporal correlation revealed between the OND rains and IOD $(r=0.6304)$ compared to ENSO $(r=0.5538)$. This scenario shows that, the anomalous warming over the western Indian Ocean has a faster response to OND rains in Tanzania than the remote influence induced by anomalous warming from the central Pacific Ocean does. The patterns associated with dry years are found to be linked with the diverged low level south easterly wind anomalies over many parts of the country. Correspondingly, there is the dominance of the cyclonic circulation to the upper level aligned with the low-level divergence. This condition enhances continuous descending motion accompanied with suppression in rainfall activities. On the other hand, dry years were associated with negative IOD, cold phase of ENSO condition, descending limb of the Walker Circulation and significant reduction in the westerly moisture flux transport sourced from Congo basin towards the western sector and Lake Victoria basin. 


\section{Acknowledgements}

The authors wish to express their sincere thanks to the Director General of Tanzania Meteorological Authority, and NCEP/NCAR for making the raingauge data and reanalysis data available.

\section{Conflicts of Interest}

The authors declare no conflicts of interest regarding the publication of this paper.

\section{References}

[1] Wani, S.P., Sreedevi, T.K., Rockström, J. and Ramakrishna, Y.S. (2009) Rainfed Agriculture-Past Trends and Future Prospects. In: Wani, S.P., Rockstrom, J. and Oweis, T., Eds., Rainfed Agriculture: Unlocking the Potential, Comprehensive Assessment of Water Management in Agriculture Series. 7, CABI, Wallingford, UK, $1-35$.

[2] Stern, R.D. and Cooper, P.J.M. (2011) Assessing Climate Risk and Climate Change Using Rainfall Data-A Case Study from Zambia. Experimental Agriculture, 47, 241-266. https://doi.org/10.1017/S0014479711000081

[3] Malozo, M. (2014) Agriculture Climate Resilience Plan 2014-2019. Ministry of Agriculture, Food Security and Cooperatives of Tanzania, Dar es Salaam, 1-2. https://www.researchgate.net/publication/323218895

[4] Omeny, P.A., Ogallo, L.A., Okoola, R.E., Hendon, H. and Wheeler, M. (2008) East African Rainfall Variability Associated with Madden Julian Oscillation. East African Rainfall Variability Ass, 2, 105-114.

[5] Verdin, J., Funk, C., Senay, G. and Choularton, R. (2005) Climate Science and Famine Early Warning. Philosophical Transactions of the Royal Society B: Biological Sciences, 360, 2155-2168. https://doi.org/10.1098/rstb.2005.1754

[6] Funk, C., Dettinger, M.D., Michaelsen, J.C., Verdin, J.P., Brown, M.E., Barlow, M., et al. (2008) Warming of the Indian Ocean Threatens Eastern and Southern African Food Security But Could Be Mitigated by Agricultural Development. Proceedings of the National Academy of Sciences of the United States of America, 105, 11081-11086. https://doi.org/10.1073/pnas.0708196105

[7] Oguntunde, P.G., Abiodun, B.J., Lischeid, G. and Merz, C. (2014) Modelling the Impacts of Reforestation on the Projected Hydroclimatology of Niger River Basin, West Africa. Ecohydrology, 7, 163-176. https://doi.org/10.1002/eco.1343

[8] Wenhaji Ndomeni, C., Cattani, E., Merino, A. and Levizzani, V. (2018) An Observational Study of the Variability of East African Rainfall with Respect to Sea Surface Temperature and Soil Moisture. Quarterly Journal of the Royal Meteorological Society, 144, 384-404. https://doi.org/10.1002/qj.3255

[9] Okoola, R.E. (1999) A Diagnostic Study of the Eastern Africa Monsoon Circulation during the Northern Hemisphere Spring Season. International Journal of Climatology, 19, 143-168.

https://doi.org/10.1002/(SICI)1097-0088(199902)19:2\%3C143::AID-JOC342\%3E3.0. CO;2-U

[10] Ogallo, L.J. (1988) Relationships between Seasonal Rainfall in East Africa and the Southern Oscillation. Journal of Climatology, 8, 31-43.

https://doi.org/10.1002/joc.3370080104 
[11] Hastenrath, S., Nicklis, A. and Greischar, L. (1993) Atmospheric-Hydrospheric Mechanisms of Climate Anomalies in the Western Equatorial Indian Ocean. Journal of Geophysical Research: Oceans, 98, 20219-20235. https://doi.org/10.1029/93JC02330

[12] Kabanda, T.A. and Jury, M.R. (1999) Inter-Annual Variability of Short Rains over Northern Tanzania. Climate Research, 13, 231-241. https://doi.org/10.3354/cr013231

[13] Indeje, M. and Semazzi, F.H.M. (2000) Relationships between QBO in the Lower Equatorial Stratospheric Zonal Winds and East African Seasonal Rainfall. Meteorology and Atmospheric Physics, 73, 227-244. https://doi.org/10.1007/s007030050075

[14] Reason, C.J.C., Allan, R.J., Lindesay, J.A. and Ansell, T.J. (2000) ENSO and Climatic Signals across the Indian Ocean Basin in the global Context: Part I, Interannual Composite Patterns. International Journal of Climatology, 20, 1285-1327. https://doi.org/10.1002/1097-0088(200009)20:11\%3C1285::AID-JOC536\%3E3.0.CO i2-R

[15] Mason, S.J. and Goddard, L. (2001) Probabilistic Precipitation Anomalies Associated with EN SO. Bulletin of the American Meteorological Society, 82, 619-638. https://doi.org/10.1175/1520-0477(2001)082\%3C0619:PPAAWE\%3E2.3.CO;2

[16] Behera, S.K., Krishnan, R. and Yamagata, T. (1999) Unusual Ocean-Atmosphere Conditions in the Tropical Indian Ocean during 1994. Geophysical Research Letters, 26, 3001-3004. https://doi.org/10.1029/1999GL010434

[17] Latif, M., Dommenget, D., Dima, M. and Grötzner, A. (1999) The Role of Indian Ocean Sea Surface Temperature in Forcing East African Rainfall Anomalies during December-January 1998. Journal of Climate, 12, 3497-3504. https://doi.org/10.1175/1520-0442(1999)012\%3C3497:TROIOS\%3E2.0.CO;2

[18] Black, E., Slingo, J. and Sperber, K.R. (2003) An Observational Study of the Relationship between Excessively Strong Short Rains in Coastal East Africa and Indian ocean SST. Monthly Weather Review, 131, 74-94. https://doi.org/10.1175/1520-0493(2003)131<0074:AOSOTR>2.0.CO;2

[19] Hastenrath, S. (2007) Circulation Mechanisms of Climate Anomalies in East Africa and the Equatorial Indian Ocean. Dynamics of Atmospheres and Oceans, 43, 25-35. https://doi.org/10.1016/j.dynatmoce.2006.06.002

[20] Preethi, B., Sabin, T.P., Adedoyin, J.A. and Ashok, K. (2015) Impacts of the ENSO Modoki and Other Tropical Indo-Pacific Climate-Drivers on African Rainfall. Scientific Reports, 5, Article No. 16653. https://doi.org/10.1038/srep16653

[21] Limbu, P.T.S. and Guirong, T. (2019) Relationship between the October-December Rainfall in Tanzania and the Walker Circulation Cell over the Indian Ocean. $\mathrm{Me}$ teorologische Zeitschrift, 28, 453-469. https://doi.org/10.1127/metz/2019/0939

[22] Kalnay, E., Kanamitsu, M., Kistler, R., Collins, W., Deaven, D., Gandin, L., et al. (1996) The NCEP/NCAR 40-Year Reanalysis Project. Bulletin of the American Meteorological Society, 77, 437-471.

[23] Smith, T.M., Reynolds, R.W., Peterson, T.C. and Lawrimore, J. (2008) Improvements to NOAA's Historical Merged Land-Ocean Surface Temperature Analysis (1880-2006). Journal of Climate, 21, 2283-2296. https://doi.org/10.1175/2007JCLI2100.1

[24] Saji, N.H., Goswami, B.N., Vinayachandran, P.N. and Yamagata, T. (1999) A Dipole Mode in the Tropical Indian Ocean. Nature, 401, 360-363.

[25] Behera, S.K., Luo, J.-J., Masson, S., Delecluse, P., Gualdi, S., Navarra, A., et al. 
(2006) Erratum: Paramount Impact of the Indian Ocean Dipole on the East African Short Rains: A CGCM Study. Journal of Climate, 18, 4514-4530.

https://doi.org/10.1175/JCLI3541.1

[26] Muhati, F., Ininda, J. and Opijah, F.J. (2007) Relationship between ENSO Parameters and the Trends and Periodic Flactuations in East African Rainfall. Journal of Kenya Meteorological Society, 1, 20-43.

[27] Roundy, P.E. (2015) On the Interpretation of EOF Analysis of ENSO, Atmospheric Kelvin Waves, and the MJO. Journal of Climate, 28, 1148-1165. https://doi.org/10.1175/JCLI-D-14-00398.1

[28] Camberlin, P. and Okoola, R.E. (2003) The Onset and Cessation of the 'Long Rains' in Eastern Africa and Their Interannual Variability. Theoretical and Applied Climatology, 75, 43-54. https://doi.org/10.1007/s00704-002-0721-5

[29] Mafuru, K.B. and Guirong, T. (2018) Assessing Prone Areas to Heavy Rainfall and the Impaction of the Upper Warm Temperature Anomaly during March-May Rainfall Season in Tanzania. Advances in Meteorology, 2018, Article ID: 8353296. https://doi.org/10.1155/2018/8353296 